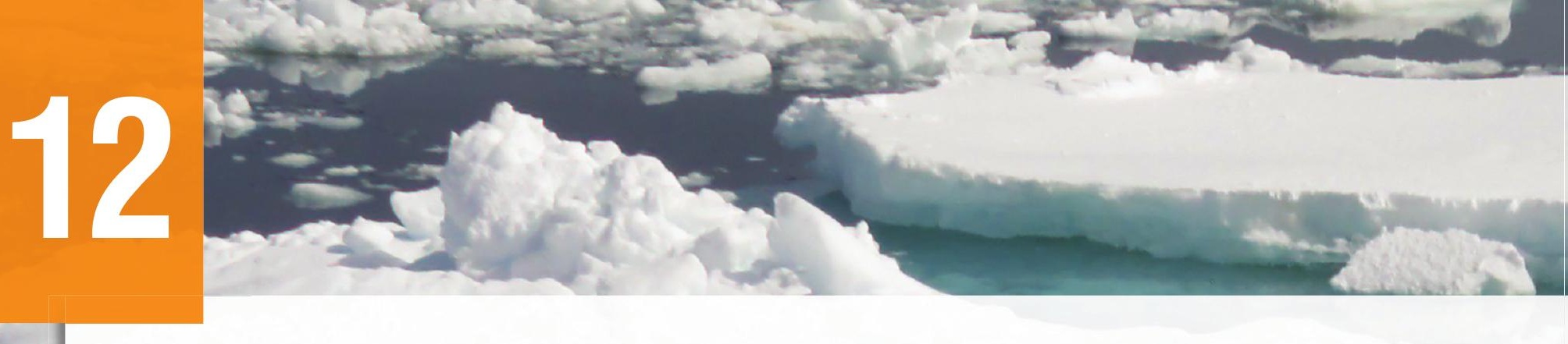

\title{
SPECIES COMPOSITION AND SPATIAL DISTRIBUTION OF ECHINODERMS IN THE SHALLOW COAST OF ADMIRALTY BAY, KING GEORGE ISLAND, ANTARCTICA
}

http://dx.doi.org/10.4322/apa.2014.115

\author{
Andre Monnerat Lanna ${ }^{1} \star$, Carlos Alberto de Moura Barboza ${ }^{2}$, Rafael Bendayan de Moura ${ }^{1}$, \\ Helena Passeri Lavrado ${ }^{3}$, Adriana Galindo Dalto ${ }^{4}$, Lúcia de Siqueira Campos ${ }^{1, * *}$ \\ 'Laboratório de Echinodermata, Departamento de Zoologia \\ ${ }^{2}$ Laboratório de Polychaeta, Departamento de Zoologia \\ ${ }^{3}$ Laboratório de Bentos, Departamento de Biologia Marinha \\ ${ }^{4}$ Laboratório de Macroalgas Marinhas, Departamento de Botânica \\ Universidade Federal do Rio de Janeiro (UFRJ), Av. Carlos Chagas Filho, 373, bloco A, sala A0-124, \\ Ilha do Fundão, CEP 21941-902, Rio de Janeiro, RJ, Brazil \\ *e-mails: andremolanna@gmail.com; **/uciascampos@gmail.com
}

\begin{abstract}
The echinoderm species composition from the shallow coast of Admiralty Bay was assessed from specimens collected during the austral summers of 2008/9 and 2010/11. Their density, diversity and community structure at four sampling stations in two bathymetric zones [shallow $(20-30 \mathrm{~m})$ and deep $(50-60 \mathrm{~m})$ ] were compared. We tested the following hypotheses based on previous environmental and biological data: 1) echinoderm density is lower in the shallowest zones; 2) diversity from the deepest zone is higher; 3) community structure differs among stations and bathymetric zones. The hypothesis that the total density is lowest in the shallowest zone was rejected, and density differed only among stations. Diversity differed only between stations, but lowest values occurred mainly in the shallowest zones. PERMANOVA analysis showed that assemblages differed between depths, there being an interaction with stations. Environmental condition differences (e.g., sediment texture) between areas and depths probably induced the highest abundance of the sea star Odontaster validus and the sea urchin Sterechinus neumayeri in the shallowest zone, and that of the brittle stars Ophionotus victorae and Amphioplus acutus in the deepest zone. These results will support future investigations that should also incorporate multiple spatial and temporal scales.
\end{abstract}

Keywords: Megafauna, Echinodermata, South Shetlands, Species Composition, Diversity.

\section{Introduction}

Admiralty Bay at the King George Island, South Shetlands, became an Antarctic Specially Managed Area (ASMA \#1) in 1996. Brazil has systematically monitored the bay since the Austral summer of 2002/03 (Montone et al., 2013). Three research stations - the Brazilian Comandante Ferraz, the Polish Henryk Arctowski, and the Peruvian Machu Picchu are located in this bay and therefore the area is subject to fairly high human scientific activities.

Echinoderms represent one of the most conspicuous groups of marine invertebrates in Antarctica (e.g., Clarke et al. 2004; Barnes, 2005; Arntz et al., 2006), and this is also the case for Admiralty Bay (Sicinski et al., 2011). They are particularly diverse in Antarctica, representing about $10 \%$ of the 4.100 known benthic species (Clarke \& Johnston, 2003). In Admiralty Bay they represent about $6 \%$ of the 1.300 known species of the benthic fauna (Sicinski et al., 2011). Echinoderms play an important role in Antarctic marine ecosystems as they are abundant and usually show patchy, but fairly high biomass (Clarke \& Johnston, 2003). Corbisier et al. (2004) recorded a wide range of feeding habits in Admiralty Bay, for instance, the sea star Odontaster validus as carnivore, the brittle star Ophionotus victoriae as omnivore, and the sea urchin Sterechinus neumayeri as herbivore (these animals represented in Figure 2). 
Nonato et al. (2000) and Sicinski et al. (2011) showed that benthic depth zonation in Admiralty Bay is essentially influenced by the sediment texture and by the action of the ice. The latter reduces the occurrence of sessile forms in shallowest zones, and generally a low diversity of organisms is dominated by wandering animals (Sicinski et al., 2011). At depths more than 20-25 m, conditions are more stable and these authors suggest that a more diverse benthic community occurs.

Taking into account the relevance of echinoderms for the Antarctic benthic communities and also the different conditions existent at different depths in the Admiralty Bay coastal marine environment, the following hypotheses were raised: 1) the density of echinoderms is lowest in the shallowest zone of the bay $(20-30 \mathrm{~m})$ in relation to the deepest zone $(50-60 \mathrm{~m})$, and it differs between distinct sampling stations; 2 ) the diversity in the shallowest zone is lower than the deepest zone and differs between sampling stations; 3) the echinoderm assemblages differ between stations and depths.

\section{Materials and Methods}

\section{Study site main features}

Admiralty Bay is the largest bay of King George Island with a maritime area of $144 \mathrm{~km}^{2}$. It is very heterogeneous and characterized as a fjord system with a $550 \mathrm{~m}$ deep central basin (Pruszak, 1980; Campos et al., 2013). The presence of blocks of ice resulting from melting icebergs and glaciers in the seawater and on beaches are common. According to Sicinski (2004), the sediment of Admiralty Bay is very heterogeneous, with several grain size fractions originated from the coastal erosion and melting of icebergs.

\section{Sampling}

Samples were taken using an "Agassiz Trawl" dredge with an opening of $56 \times 36 \mathrm{~cm}$, a bottom sack of $60 \mathrm{~cm}$ long and a $4 \mathrm{~mm}$ mesh size at four monitoring stations: Refuge II (R2), Ferraz Station (FS), Ullman Point (UP) and Botany Point (BP) (Figure 1), in two bathymetric zones during

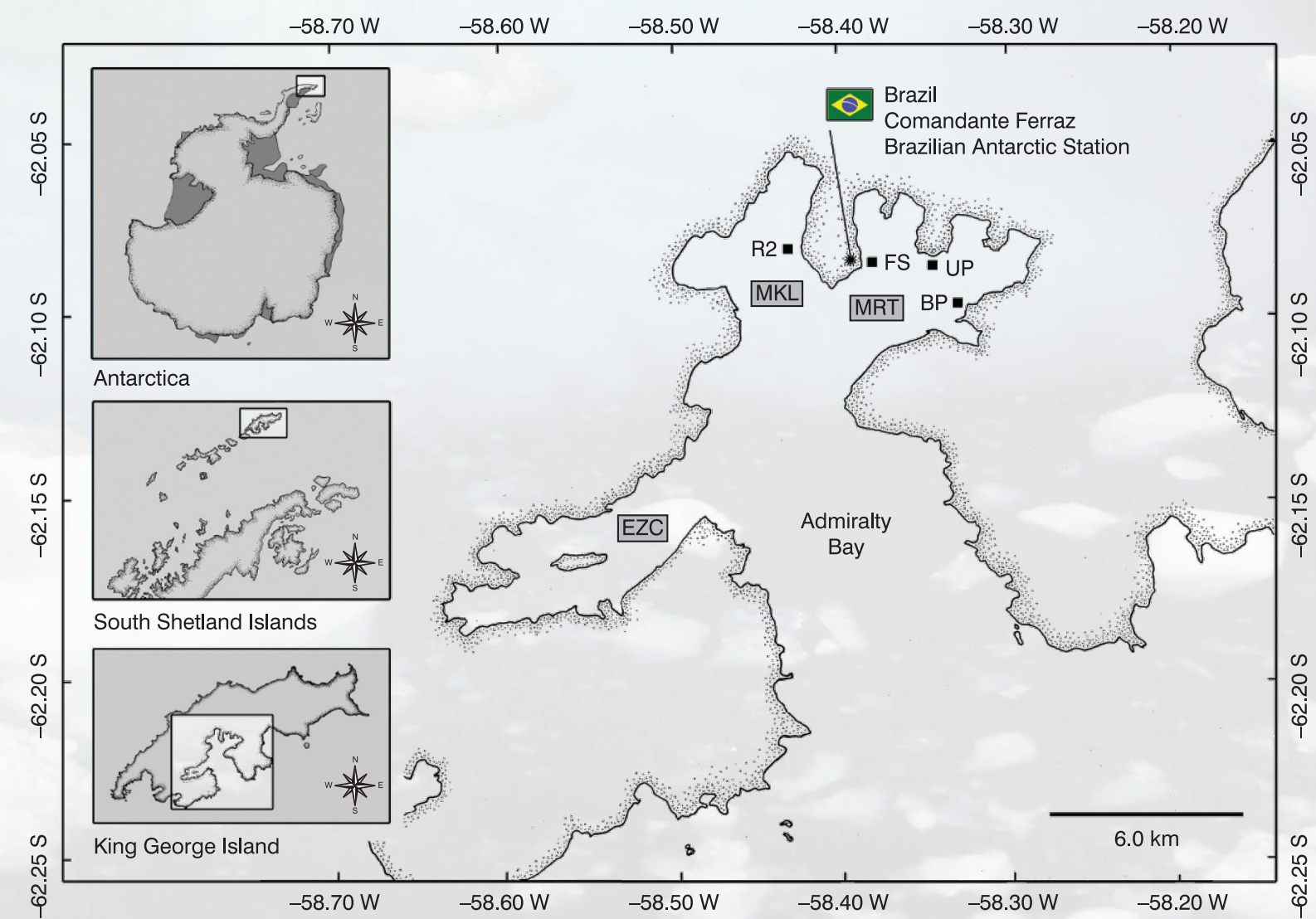

Figure 1. Study area, in highlight Admiralty Bay with three inlets (Ezcurra (EZC), Mackellar (MKL) and Martel (MRT)) and the four sampling stations. R2 = Refuge Il; FS = Ferraz Station; UP = Ullman Point; BP = Botany Point. Modified from Moura (2009). 


\section{Results}

A total of 2.473 echinoderms were collected, represented by 18 species in seven families of sea stars, three of sea urchins, three of sea cucumbers and two of brittle stars (Table 1).

The total density and that of $O$. victoriae differed only between stations, being lowest at Refuge II. A difference occurred between depths, where the density of A. acutus was highest in the deepest zone, and that for O. validus in the shallowest zone. The density of $S$. neumayeri was highest in the shallowest zones of the bay, there being a significant interaction between station-depth (Figure 3; Table 2).

The diversity of echinoderms differed between stations. The lowest values occurred at Botany Point, especially in the shallowest zone. But generally, the diversity did not differ between the shallowest and deepest zones (Figure 3; Table 2).

The principal components analysis explained $60 \%$ of the biological variability and the diagram divided the stations into two main groups, shallowest and deepest zones (Figure 4.). S. neumayeri and O. validus were associated with the shallowest zone, whilst $A$. acutus and O. victoriae were associated with the deepest zone. PERMANOVA analysis corroborated the results found using the PCA, showing that echinoderm assemblages differed between bathymetric zones, but there was a significant interaction within stations (Table 3).

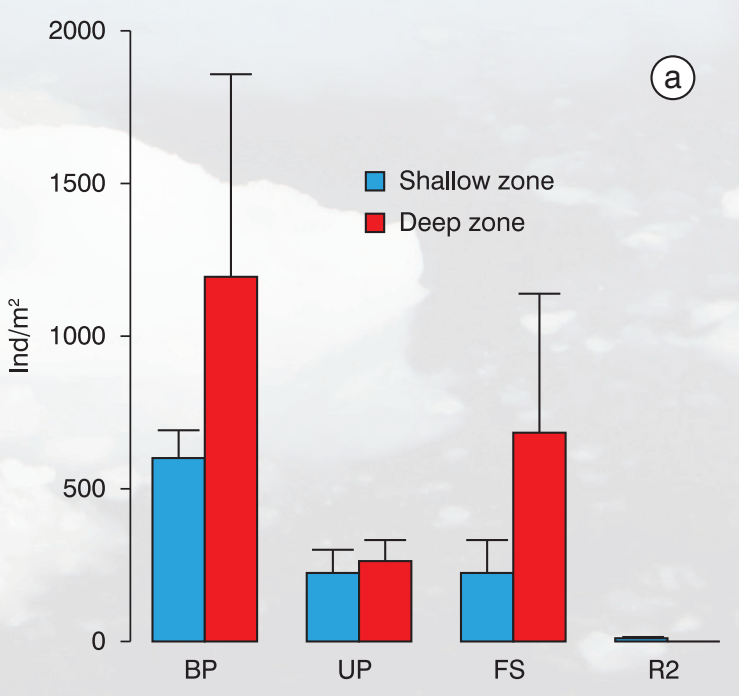

\section{Discussion}

In this study, 18 species of echinoderms were registered. This is equivalent to $22 \%$ of the total echinoderm species (81 species) known for Admiralty Bay (Sicinski et al., 2011). Ice scouring along the seabed (Nonato et al., 2000), as well as anthropogenic disturbances (Martins et al., 2012) have been mentioned as the main drivers for benthic bathymetric variability in the shallow coastal zones of Admiralty Bay. Even though these may influence communities' structure (Sicinski et al., 2011), we rejected the hypothesis that the total echinoderm density decreases in the shallowest zones here sampled.

Conversely, the density of the echinoderms differed among sampling stations, and was lowest in Refuge II, where during the studied Austral summers (2008/09 and 2010/11) a considerable amount of blocks of ice was observed, even though not recorded. This ice was probably derived from the Domeiko Glacier, which occupies an extensive area of Mackellar Inlet. The effect of anchor ice and ice scour could be the main causes for the low community density at the Refuge II sampling station. And this might have been true for both bathymetric zones analysed here, as the echinoderms showed low densities in both the shallowest and deepest zones. In high latitudes, processes such as anchor ice and ice scour are common in the bottom of bays, and are known to cause disturbances in benthic

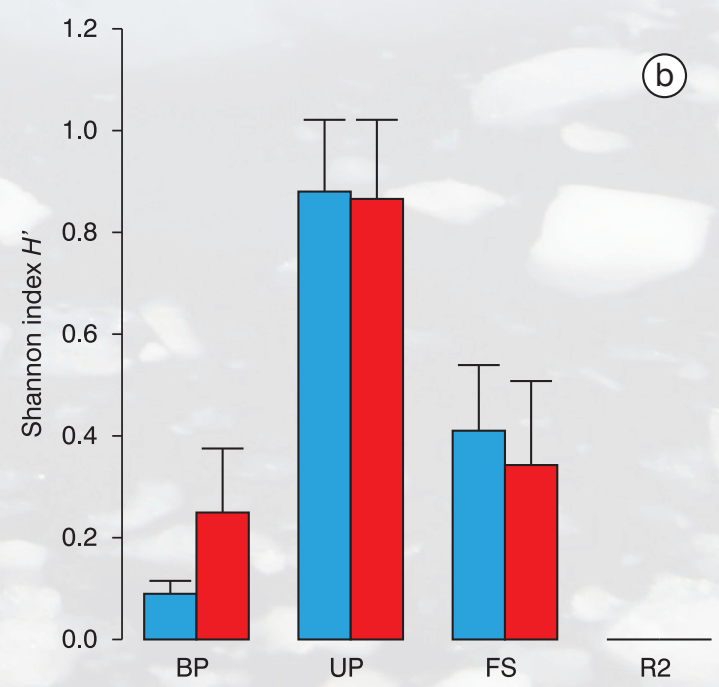

Figure 3. a) Density $( \pm S D)$ and b) Diversity $( \pm S D)$ of the echinoderms in the four sampling stations, in the shallow and deep zones in Admiralty Bay. BP $=$ Botany Point; UP = Ullman Point; FS = Ferraz Station; R2 = Refuge II. 


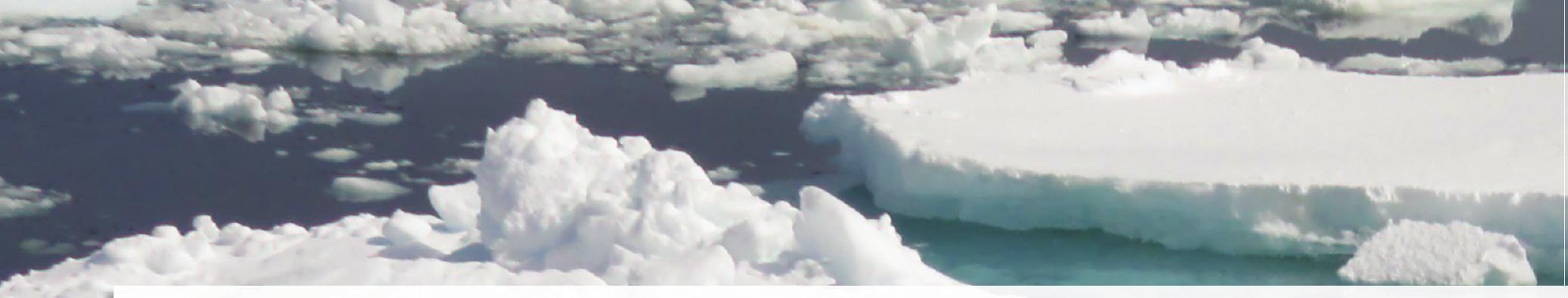

communities, as well as freezing or even crushing the organisms, and therefore reducing diversity (Gutt, 2001). The slower speed of the tidal currents in the Mackellar Inlet

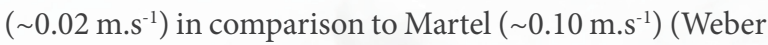
\& Montone, 2006) could reduce salinity condition and increase turbidity during the summer, accentuated by the melting ice. As echinoderms are typically marine organisms with low tolerance for salinity changes, these processes should be considered important regulatory sources for their distribution within Admiralty Bay.

Differences between depths were found when the species densities were investigated separately. For example, the density of the amphiurid brittle star A. acutus was always highest in the deepest zone of the bay. In general, amphiurids are infaunal deposit feeders, and characteristically live in muddy sediments (Rosenberg, 1995). The Admiralty Bay

Table 1. Echinoderms species collected in Admiralty Bay, King George Island, Antarctica.

\begin{tabular}{|c|c|c|}
\hline \\
\hline \multicolumn{3}{|c|}{ Class Asteroidea } \\
\hline & & Acodontaster conspicuus (Koehler, 1920) \\
\hline & & Odontaster validus Koehler, 1906 \\
\hline & Family Ganeriidae & \\
\hline & & Perknaster charcoti (Koehler, 1912) \\
\hline & Family Poraniidae & \\
\hline & & Porania antarctica (Smith, 1876) \\
\hline & Family Korethrasteridae & \\
\hline & & Remaster gourdoni Koehler, 1912 \\
\hline & Family Solasteridae & \\
\hline & & Cuenotaster involutus (Koehler, 1912) \\
\hline & Family Asteriidae & \\
\hline & & Diplasterias brucei (Koehler, 1908) \\
\hline & Family Astropectinidae & \\
\hline & & Psilaster charcoti (Koehler, 1906) \\
\hline Class Echinoidea & & \\
\hline & Family Echinidae & \\
\hline & & Sterechinus neumayeri (Meissner, 1900) \\
\hline & Family Schizasteridae & \\
\hline & & Abatus sp. \\
\hline & Family Ctenocidaridae & \\
\hline & & Ctenocidaris rugosa (Koehler, 1926) \\
\hline Class Holothuroide: & & \\
\hline & Family Psolidae & \\
\hline & & Psolus charcoti Vaney, 1906 \\
\hline & Family Cucumariidae & \\
\hline & & Cucumaria georgiana (Lampert, 1886) \\
\hline & & Trachythyone bouvetensis (Ludwig \& Heding, 1935) \\
\hline & Family Molpadiidae & \\
\hline & & Molpadia musculus Risso, 1826 \\
\hline Class Ophiuroidea & & \\
\hline & Family Ophiuridae & \\
\hline & & Ophionotus victoriae Bell, 1902 \\
\hline & & Ophiura rouchi (Koehler, 1902) \\
\hline & Family Amphiuridae & \\
\hline & & Amphioplus acutus Mortensen, 1936 \\
\hline
\end{tabular}




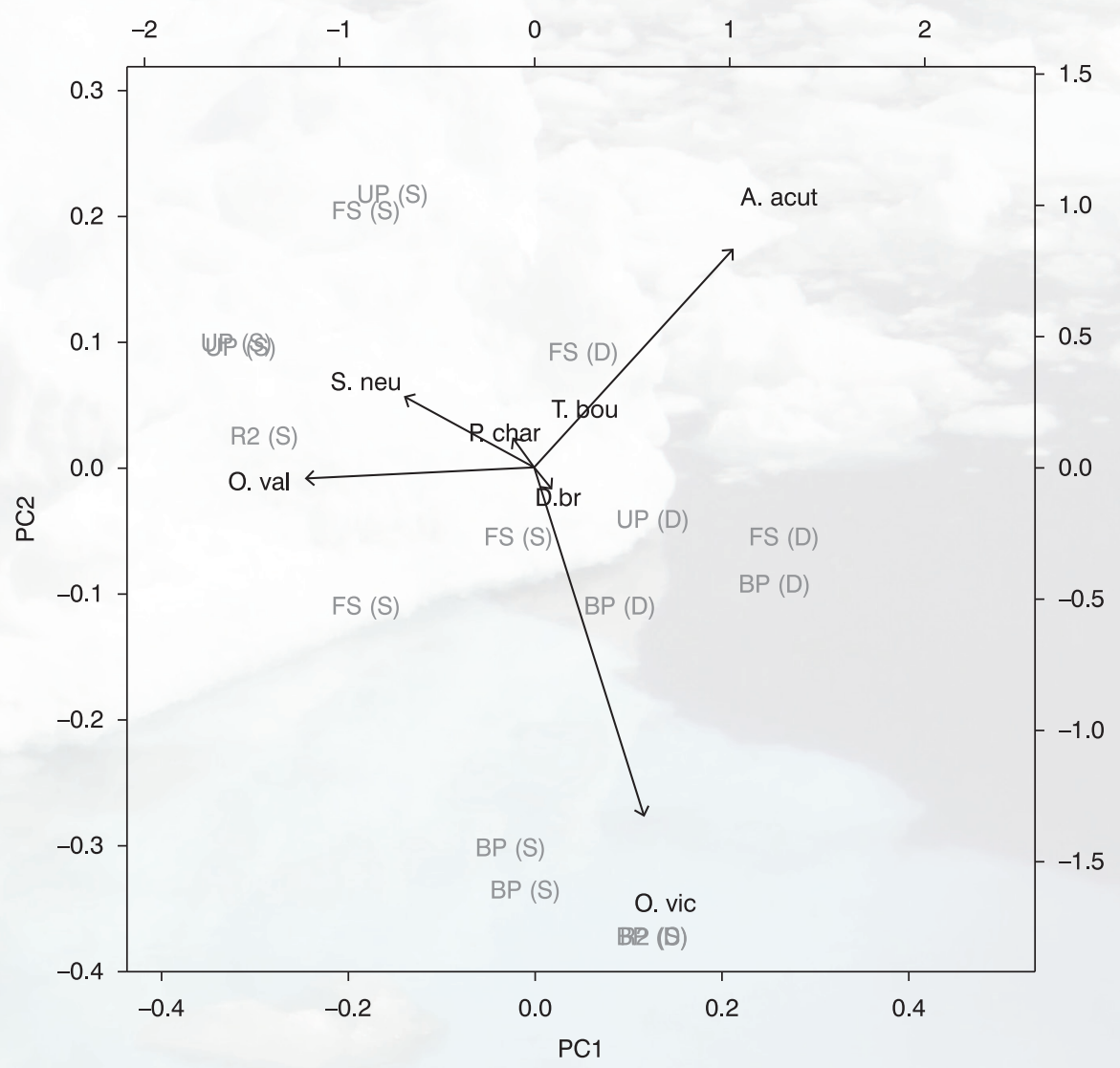

Figure 4. PCA diagram of echinoderm species. (O.val) O. validus, (S.neu) S. neumayeri, (A.acut) A. acutus, (O.vic) O. victoriae, (P.char) P. charcoti, (D.br) D. brucei, (T.bou) T. bouvetensis. R2(S) = Refuge II Shallow; FS(S) = Ferraz Station Shallow; UP(S) = Ullman Point Shallow; BP(S) = Botany Point Shallow; $\mathrm{R} 2(\mathrm{D})=$ Refuge II Deep; FS(D) = Ferraz Station Deep; UP(D) = Ullman Point Deep; BP(D) = Botany Point Deep.

shallowest zones consist of predominantly thick sediment with a significant presence of pebbles, while the deepest zone is characterised by muddy sediment (Schaefer et al., 2004), and this would possibly explain the highest density of A. Acutus at this zone. S. neumayeri, a macroalgae consumer (Corbisier et al., 2004), was more abundant in the shallowest zones. We expected that this could be positively related to the macroalgae biomass found in these zones. And a regression of the density of $S$. neumayeri against the biomass of macroalgae showed a significant positive relationship ( $\mathrm{n}=12, p<0.05$ ) between them. Large quantities of macroalgae were found in Ferraz and Ullman Point, creating suitable conditions for the dominance of $S$. neumayeri. The lack of macroalgae from the Botany Point samples could be related to the intake of melting water with terrigenous material originated from the Krak Glacier. This would cause high turbidity and reduce the photic layer, being less suitable for the algae growth. S. neumayeri was not recorded from this sampling station. This was the reason of the interaction between the station-depth found in the ANOVA analysis.

The hypothesis that the diversity is highest in the deepest zones was not corroborated. The evidence suggested that regulatory processes controlling diversity do not have an effect on the bathymetric scale sampled. Although the values of diversity found were similar, the PCA diagram and the PERMANOVA analysis showed that the assemblages differed between depths. The sea star Odontaster validus and sea urchin $S$. neumayeri were more abundant in shallowest zones, the latter absent in deepest zones, while the brittle stars A. acutus and O. victorae were abundant in deepest zones, and rare in shallowest zones. Also, diversity was different between stations. Ullman Point showed the highest 


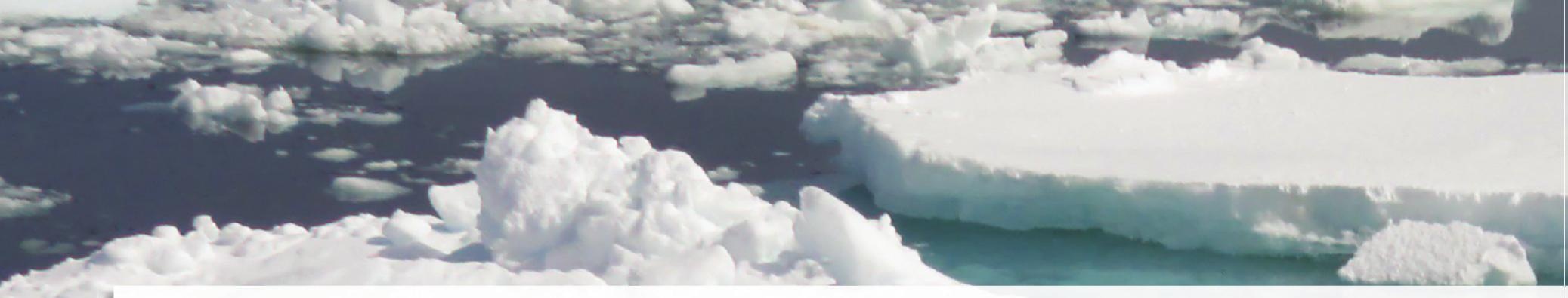

Table 2. Summary of ANOVA analysis of the total density, density of Ophionotus victoriae, Amphioplus acutus, Sterechinus neumayeri, Odontaster validus and diversity. DF = Degrees of Freedom; SS = Sum of Squares; MS = Mean of Squares. Values of $p$ in bold $<0.05$.

\begin{tabular}{|c|c|c|c|c|c|}
\hline \multicolumn{6}{|c|}{ Density (Echinoderms) } \\
\hline Factor & DF & SS & MS & $\mathrm{F}$ & $p$ \\
\hline Station & 3 & 82.844 & 27.614 & 13.233 & 0.031 \\
\hline Depth & 1 & 0.326 & 0.3259 & 0.237 & 0.633 \\
\hline Depth $\times$ Station & 3 & 6.26 & 2.086 & 1.517 & 0.248 \\
\hline Residuals & 16 & 22.003 & 1.3752 & & \\
\hline \multicolumn{6}{|c|}{ Ophionotus victoriae } \\
\hline Station & 3 & 106.117 & 35.372 & 13.1637 & 0.031 \\
\hline Depth & 1 & 0.045 & 0.045 & 0.0094 & 0.924 \\
\hline Depth $\times$ Station & 3 & 8.061 & 2.687 & 0.5568 & 0.651 \\
\hline Residuals & 16 & 77.216 & 4.826 & & \\
\hline \multicolumn{6}{|l|}{ Amphioplus acutus } \\
\hline Station & 3 & 33.969 & 11.323 & 1.6865 & 0.339 \\
\hline Depth & 1 & 47.314 & 47.314 & 21.9432 & 0.000 \\
\hline Depth $\times$ Station & 3 & 20.142 & 6.714 & 3.1138 & 0.056 \\
\hline Residuals & 16 & 34.499 & 2.156 & & \\
\hline \multicolumn{6}{|c|}{ Sterechinus neumayeri } \\
\hline Station & 3 & 32.638 & 10.879 & 1 & 0.500 \\
\hline Depth & 1 & 31.384 & 31.384 & 86.465 & 0.000 \\
\hline Depth $\times$ Station & 3 & 32.638 & 10.879 & 29.973 & 0.000 \\
\hline Residuals & 16 & 5.808 & 0.363 & & \\
\hline \multicolumn{6}{|c|}{ Odontaster validus } \\
\hline Station & 3 & 1.5362 & 0.5121 & 0.2883 & 0.833 \\
\hline Depth & 1 & 22.231 & 22.231 & 27.6415 & 0.000 \\
\hline Depth $\times$ Station & 3 & 5.3284 & 1.7761 & 2.2084 & 0.127 \\
\hline Residuals & 16 & 12.8682 & 0.8043 & & \\
\hline \multicolumn{6}{|l|}{ Diversity } \\
\hline Station & 3 & 2.54815 & 0.84938 & 57.8906 & 0.000 \\
\hline Depth & 1 & 0.00282 & 0.00282 & 0.0706 & 0.790 \\
\hline Depth $\times$ Station & 3 & 0.04402 & 0.01467 & 0.3678 & 0.780 \\
\hline Residuals & 16 & 0.63827 & 0.03989 & & \\
\hline
\end{tabular}

Table 3. Summary of PERMANOVA analysis. DF = Degrees of freedom; $S S=$ Sum of squares; $M S=$ Mean of squares. $p(M C)$ probability of Monte Carlo permutation.

\begin{tabular}{|c|c|c|c|c|c|c|}
\hline Factor & DF & ss & MS & $\mathbf{F}$ & $P($ perm $)$ & $p(\mathrm{MC})$ \\
\hline Station & 3 & 3.3631 & 1.1210 & 1.1060 & 0.3942 & 0.4281 \\
\hline Depth & 1 & 3.3033 & 3.3033 & 10.4893 & 0.0001 & 0.0001 \\
\hline Depth $\times$ Station & 3 & 3.0408 & 1.0136 & 3.2186 & 0.0002 & 0.0009 \\
\hline Residuals & 16 & 5.0388 & 0.3186 & & & \\
\hline
\end{tabular}




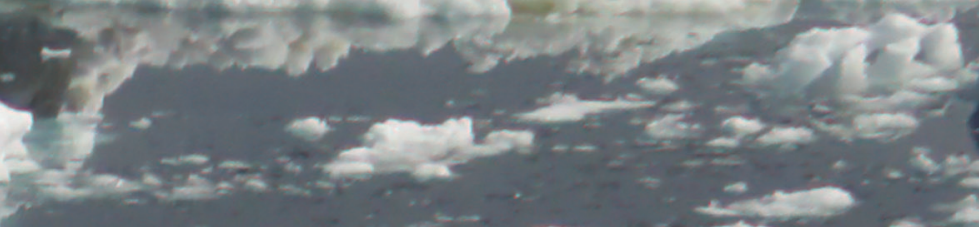

diversity followed by Ferraz and Botany. Despite the fact that the highest density and species richness occurred in Botany, diversity there was depressed by the dominance of O. victoriae.

Conlan et al. (2004) reported that marine benthos is affected by sewage discharges from McMurdo Station. These authors showed declined diversity and changes of the dominant species in that area. Previous studies (e.g. Schaefer et al., 2004, Santos et al., 2005) pointed out high values of total organic matter in the vicinity of Ferraz in comparison with those obtained in other reference areas (Botany, Hennequin and Arctowski) from Admiralty Bay. Montone et al. (2010) reported high values of faecal steroids in front of Ferraz. Also, the Ferraz sewage appear to influence an area up to approximately $200 \mathrm{~m}$ distant from its effluent (Montone et al., 2013), which includes the $60 \mathrm{~m}$ isobath sampled here. However, our results showed that possible disturbances caused by sewage discharges not necessarily could be considered as a primary source for the variability in echinoderms distribution. They were fairly dense and diverse in front of Ferraz Station compared to other stations.

\section{Conclusion}

The total echinoderm density and diversity were investigated here against two different depth ranges (20-30 $\mathrm{m}$ and 50-60 $\mathrm{m}$ ) and sampling stations within Admiralty Bay. Differences occurred when the species were analysed separately, probably because of their different biological characteristics, such as the preference for certain sedimentary textures (e.g., A. acutus), or feeding habits (e.g., S. neumayeri). Future studies should adopt multiple spatial and temporal scales, as the region is characterised by large temporal and spatial variability (Sicinski et al., 2011). Also, it would be relevant to study the echinoderms in relation to other biotic factors, as well as the abiotic ones, taking into account that they may

play different roles in the benthic communities according to their niche and feeding habits.

Although previous studies indicated a possible anthropogenic impact in front the Ferraz Station, our results did not corroborate this evidence. The differences found in density, diversity and in the echinoderm assemblages were probably caused by distinct environmental features between the sampling stations, and biological factors related to the community structure in each area. Further studies on echinoderms' distribution in relation to biotic and abiotic factors, including other areas and bathymetric zones from Admiralty Bay (besides the ones shown here) would be relevant to better understand their role in the benthic communities in this ASMA.

\section{Acknowledgements}

The research study is part of the IPY project MABIREH/ CAML (CNPq/API - Process No. 52.0293/2006-1), and the Brazilian National Institute of Science and Technology on Antarctic Environmental Research (INCT-APA), which is financed by the National Council for Research and Development (CNPq Process No. 574018/2008-5), and Carlos Chagas Research Support Foundation of the State of Rio de Janeiro (FAPERJ Process No. E-16/170.023/2008). The authors also acknowledge the support of the Brazilian Ministries of Science, Technology and Innovation (MCTI), of Environment (MMA) and Inter-ministerial Commission for the Sea Resources (CIRM). Authors attending Graduate Programs: Andre Monnerat Lanna (MSc student in Animal Biology of the Programa de Pós-Graduação em Biologia Animal, Universidade Federal do Espírito Santo - UFES); Carlos Alberto de Moura Barboza (PhD student in Marine Biology of the Programa de Pós-Graduação em Biologia Marinha da Universidade Federal Fluminense - UFF); Rafael Bendayan de Moura (PhD student in Animal Biology of the Programa de Pós-Graduação em Biologia Animal, Universidade Federal de Pernambuco - UFPE).

\section{References}

Anderson, M.J. (2005). PERMANOVA: a FORTRAN computer program for permutational multivariate analysis of variance. Department of Statistics, University of Auckland, New Zealand. 


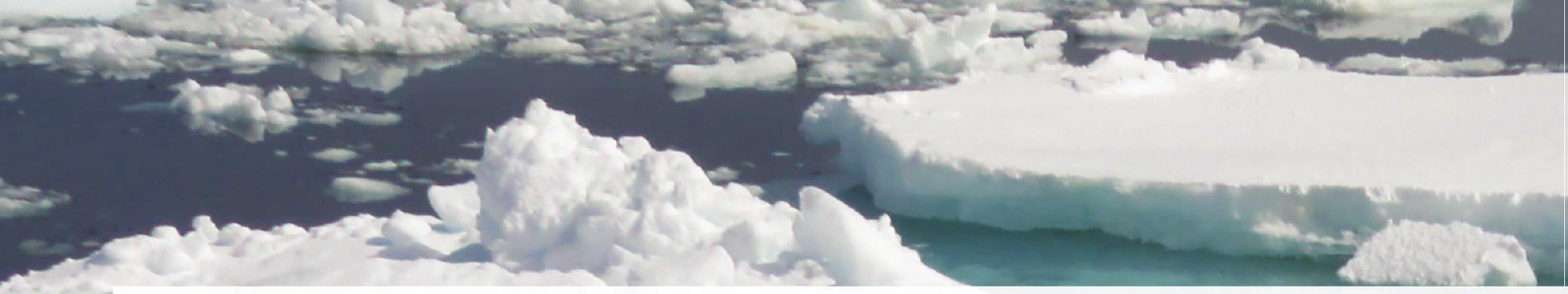

Arntz, W.E.; Thatje, S.; Linse, K.; Avila, C.; Ballesteros, M.; Barnes, D.K.A.; Cope, T.; Cristobo, F.J.; Broyer, C.D.; Gutt, J.; Isla, E.; López-González, P.; Montiel, A.; Munilla, T.; Esplá, A.A.R.; Raupach, M.; Rauschert, M.; Rodríquez, E. \& Teixidó, N. (2006). Missing link in the Southern Ocean: sampling the marine benthic fauna of remote Bouvet Island. Polar Biology, 29 : 83-96.

Barnes, D.K.A. (2005). Changing chain: past, present and future of the Scotia Arc's and Antarctica's shallow benthic communities. Scientia Marina, 69: 65-89.

Campos, L.S.; Barboza, C.A.M.; Bassoi, M.; Bernardes, M.; Bromberg, S.; Corbisier, T.N.; Fontes, R.F.C.; Gheller, P.F.; Hajdu, E.; Kawall, H.G.; Lange, P.K.; Lanna, A.M.; Lavrado, H.P.; Monteiro, G.C.S.; Montone, R.C.; Morales, T.; Moura, R.B.; Nakayama, C.R.; Oackes, T.; Paranhos, R.; Passos, F.D.; Petti, M.A.V.; Pellizari, V.H.; Rezende, C.E.; Rodrigues, M.; Rosa, L.H.; Secchi, E.; Tenenbaum, D.R. \& Yoneshigue-Valentin, Y. (2013). Chapter 8 - Environmental Processes, Biodiversity and Changes in Admiralty Bay, King George Island, Antarctica. In: Verde, C. \& di Prisco, G. (eds.), Adaptation and Evolution in Marine Environments, Volume 2, From Pole to Pole, Springer-Verlag Berlin Heidelberg.

Clarke, A. \& Johnston, N.M. (2003). Antarctic marine benthic diversity. Oceanography and Marine Biology: An Annual Review 41, 47-114.

Clarke, A.; Aronson, R.B.; Crame, J.A.; Gili, J.M. \& Blake, D.B., (2004). Evolution and diversity of the benthic fauna of the Southern Ocean continental shelf. Antarctic Science 16 (4): 559-568.

Conlan, K.E.; Kim, S.L.; Lenihan, H.S. \& Oliver, J.S. (2004). Benthic changes during 10 years of organic enrichment by Mc Murdo Station, Antarctica. Marine Pollution Bulletin, 49: 43-60.

Corbisier, T.N., Petti, M.A.V., Skowronski, R.S.P. \& Brito, T.A.S., (2004). Trophic relationships in the nearshore zone of Martel Inlet (King George Island, Antarctica): d13C stable-isotope analysis. Polar Biology 27, 75-82.

Gutt, J. (2001). On the direct impact of ice on marine benthic communities, a review. Polar Biology, 24: 553-564.

Legendre, P. \& Gallagher, E.D. (2001). Ecologically meaningful transformations for ordination of species data. Oecologia. 129: 271-280.

Martins, C.C.; Aguiar, S.N.; Bícego, M.C. \& Montone, R.C. (2012). Sewage organic markers in surface sediments around the Brazilian Antarctic station: Results from the 2009/10 austral summer and historical tendencies. Marine Pollution Bulletin 64: 2867-2870

Montone, R.C.; Martins, C.C.; Bícego, M.C.; Taniguchi, S.; Silva, D.A.M.; Campos, L.S. \& Weber, R.R. (2010). Distribution of sewage input in marine sediments around a maritime Antarctic research station indicated by molecular geochemical indicators. Science of the Total Environment 408: 4665-4671.

Montone, R.C.; Alvarez, C.E.; Bícego, M.C.; Braga, .S.; Brito, T.A.S.; Campos, L.S.; Fontes, R.F.C.; Castro, B.M.; Corbisier, T.N.; Evangelista, H.; Francelino, M.; Gomes, V.; Ito, R.G.; Lavrado, H.P.; Leme, N.P.; Mahiques, M.M.; Martins, C.C.; Nakayama, C.R.; Ngan, P.V.; Pellizari, V.H.; Pereira, A.B.; Petti, M.A.V.; Sander, M.; Schaefer, C.E.G.R. \& Weber R.R. (2013). Chapter 9 - Environmental Assessment of Admiralty Bay, King George Island, Antarctica. In: Verde, C. \& di Prisco, G. (eds.), Adaptation and Evolution in Marine Environments, Volume 2, From Pole to Pole, Springer-Verlag Berlin Heidelberg.

Moura, R.B. (2009). Estudo taxonômico dos Holothuroidea (Echinodermata) das Ilhas Shetland do Sul e do Estreito de Bransfield, Antártica. Dissertação de Mestrado, Museu Nacional, Universidade Federal do Rio de Janeiro.

Nonato, E.F.; Brito, T.A.S.; Paiva, P.C.; Petti, M.A.V. \& Corbisier, T.N. (2000). Benthic megafauna of the nearshore zone of Admiralty Bay (King George Island, South Shetland Islands, Antarctica): depth zonation and underwater observations. Polar Biology 23:580-588.

Oksanen, J.; Blanchet, F.G.; Kindt, R.; Legendre, P.; Minchin, P.R.; O'Hara, R.B.; Simpson, G.L.; Solymos, P.; Henry M.; Stevens, H. \& Wagner, H. (2011) Package 'vegan'.

Pruszak, Z. (1980). Currents circulation in the Waters of Admiralty bay (region of Arctowski Station on King George Island). Polish Polar Research, 1:55-74. 
R Development Core Team. (2007). R: A language and environment for statistical computing. R Foundation for Statistical Computing, Vienna, Austria. Available from: <http://www.R-project.org >

Rosenberg, R. (1995). Benthic marine structured by hydrodynamic processes and food availability. Netherlands Journal of Sea Research 34 (4): 303-317.

Sandrini-Neto, L. \& Camargo, M.G. (2011). GAD: Analysis of variance from general principles.

Santos, I.R.; Silva-Filho, E.V.; Schaefer, C.E.; Albuquerque-Filho, M.R. \& Campos, L.S. (2005). Heavy metals contamination in coastal sediments and soils near the Brazilian Antarctic Station, King George Island. Marine Pollution Bulletin, 50:185-194.

Schaefer, C.E.G.R.; Dias, L.E.; Campos, L. S.; Albuquerque Filho, M.R.; Costa, L.M. \& Borges Júnior, M. (2004). Monitoramento ambiental em sedimentos costeiros da Baía do Almirantado: granulometria, teores de macronutrientes e metais biodisponíveis. In: Schaefer, C.E.G.R.; Francelino, M.R.; Simas, F.N.B. \& Albuquerque-Filho, M.R. (eds) Ecossistemas costeiros e monitoramento ambiental da Antártica Marítima, Baía do Almirantado, Ilha Rei George. NEPUT - Departamento de Solos - Universidade Federal de Viçosa, Viçosa, $192 \mathrm{p}$

Sicinski, J. (2004). Polychaetes of Antarctic sublittoral in the proglacial zone (King George Island, South Shetland Islands). Polish Polar Research 25:67-96.

Sicinski, J; Jazdzewski, K.; De Broyer, C.; Presier, P.; Ligowski, R.; Nonato, E.F.; Corbisier, T.N.; Petti, M.A.V.; Brito, T.A.S.; Lavrado, H.P.; Blazewicz-Paszkowycz, M.; Pabis, K.; Jazdzewska, A. \& Campos, L.S. (2011). Admiralty Bay Benthos Diversity - A census of a complex polar ecosystem. Deep-Sea Research II.

Weber, R.R. \& Montone, R.C. (2006). Rede 2: Gerenciamento ambiental da Baía Almirantado, Ilha Rei George, Antártica. 252 p. 